\title{
Warm summers and ion concentrations in snow: comparison of present day with Medieval Warm Epoch from snow pits and an ice core from Lomonosovfonna, Svalbard
}

\author{
K. VIRKKUNEN, ${ }^{1,2}$ J. C. MOORE, ${ }^{1}$ E. ISAKSSON, ${ }^{3}$ V. POHJOLA, ${ }^{4}$ P. PERÄMÄKI, ${ }^{2}$ \\ A. GRINSTED, ${ }^{1,5}$ T. KEKONEN ${ }^{1,2}$ \\ ${ }^{1}$ Arctic Centre, University of Lapland, Box 122, FIN-96101 Rovaniemi, Finland \\ E-mail: kristiina.virkkunen@ulapland.fi \\ ${ }^{2}$ Department of Chemistry, Box 3000, University of Oulu, FIN-90014 Oulu, Finland \\ ${ }^{3}$ Norwegian Polar Institute, Polar Environmental Centre, NO-9296 Tromsø, Norway \\ ${ }^{4}$ Department of Earth Sciences, Villavägen 16, SE-752 36 Uppsala University, Uppsala, Sweden \\ ${ }^{5}$ Department of Geophysics, Box 3000, University of Oulu, FIN-90014 Oulu, Finland
}

\begin{abstract}
Snow pits sampled during two consecutive years $(2001,2002)$ at the summit of Lomonosovfonna ice cap in central Spitsbergen, Svalbard, showed that ion concentrations were spatially homogeneous. The snowpack on Lomonosovfonna shows no evidence of aerosol deposition from Arctic haze, in contrast to Holtedahlfonna (a glacier at a similar altitude in northern Spitsbergen) where there is a clear signature. In common with many other ice caps in the Arctic, Lomonosovfonna experiences periodic melting, and the deepest of the snow pits contained a record of one exceptionally warm (2001) and one long summer (2000). The most easily eluted species are nitrate and the divalent ions. Very low ion concentrations and high values of a melt indicator $\log \left(\left[\mathrm{Na}^{+}\right] /\left[\mathrm{Mg}^{2+}\right]\right)$ were a result of either deep percolation or runoff of ions during melting. Comparing the snow-pit record with the ion record of more than 800 years from an ice core drilled on Lomonosovfonna in 1997 reveals some layers with similar composition to those that suffered significant melting in the snowpack: a few years in the 20th century and around $A D 1750$, and all of the core from before $A D 1200$ show unusually heavy melting.
\end{abstract}

\section{INTRODUCTION}

Snow scavenges many impurities from the atmosphere as it falls, and chemical analysis of the snowpack therefore provides information on the chemical composition of air masses. However, the chemical record can be altered by post-depositional changes. On Lomonosovfonna, Svalbard (Fig. 1), winter surface snow contains a record of chemistry that normally has not been altered by melting. Thus, by the end of winter, the snowpack records the seasonal variation of different species in the atmosphere spanning much of the previous year. If snow pits are made at the same place during at least two consecutive years, they can provide direct evidence about species elution, since the same layers can be analyzed both before and after seasonal melting.

Summer melting occurs almost everywhere in the Arctic, except on the highest parts of Greenland. Therefore, it is generally essential to understand the impact of melting on the stratigraphic record in order to interpret the ice-core records. Percolation during warm periods homogenizes the snow chemistry and reduces the seasonal variations that are often used for dating purposes. In addition, some ions (e.g. $\mathrm{SO}_{4}{ }^{2-}$ and $\mathrm{NO}_{3}{ }^{-}$) are known to elute preferentially during melting periods (Brimblecombe and others, 1985; Tsiouris and others, 1985; Cragin and others, 1996), and thus the ion ratios preserved in ice cores may not reflect their original proportions during precipitation. The meltwater either flows deeper in the snowpack and then refreezes or the eluted ions are lost by runoff. Melting in ice cores drilled from areas with periodic melting has been studied, to demonstrate their reliability for palaeoclimatic reconstructions (e.g. Goto-Azuma and others, 2002; lizuka and others, 2002; Pohjola and others, 2002a).
The spatial distribution of snow cover and its physical and chemical characteristics in Spitsbergen are influenced by distance from the open sea, altitude above sea level, the continentality of the site and local geography (Semb and others, 1984; Głowacki and Pulina, 2000; Simões and Zagorodnov, 2001). Semb and others (1984) show that the concentrations of sea-salt components in snow samples in

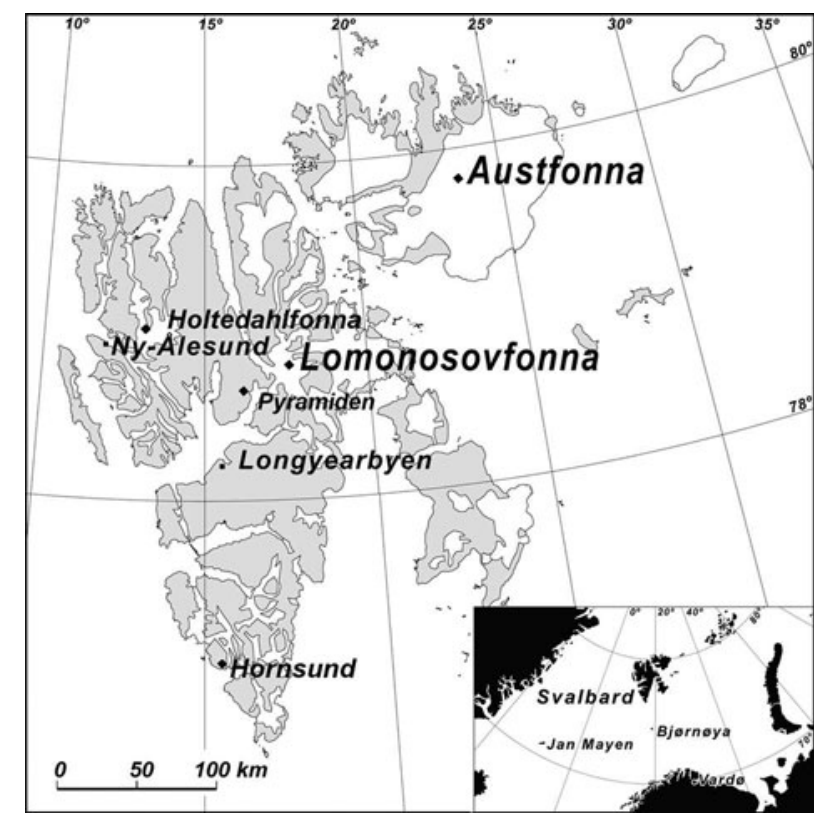

Fig. 1. Location of snow-pit sampling sites, Lomonosovfonna and Holtedahlfonna, in Svalbard. 


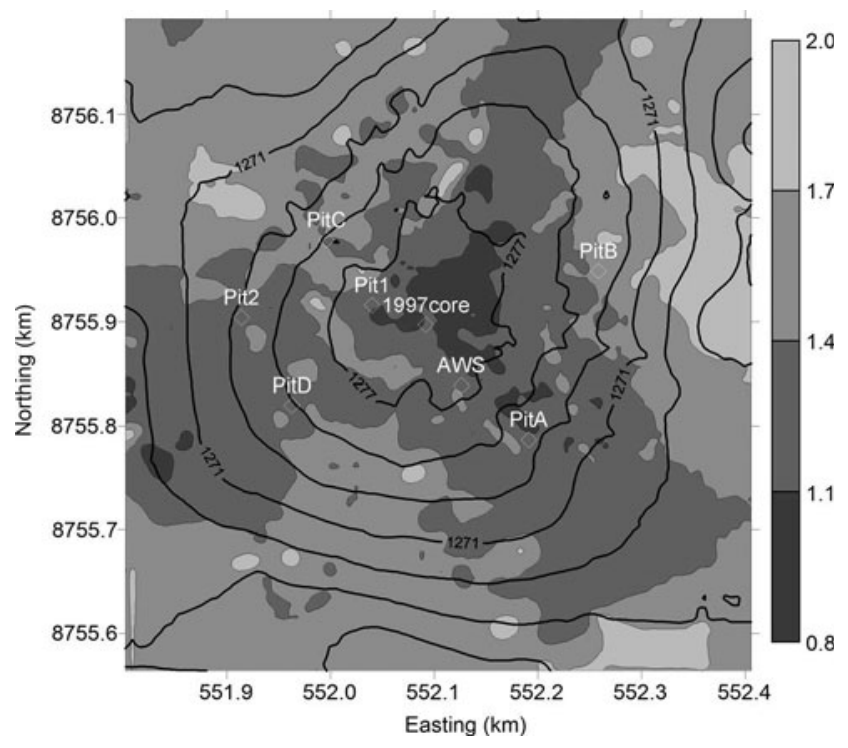

Fig. 2. The summit area of Lomonosovfonna ice cap in 2002 with surface elevation contours $(\mathrm{m})$. The map shows the locations of snow pits sampled in 2001 (pits 1 and 2), 2002 (pits A-D), the icecore drilling site in 1997 and the automatic weather station (AWS) location in 2002. Winter accumulation data based on radar measurements are presented by different shades of grey, which indicate the depth $(\mathrm{m})$ to a prominent reflection horizon expected to be the summer surface. Coordinate system is UTM-N zone 33.

Svalbard generally decrease with altitude while the $\mathrm{nsSO}_{4}{ }^{2-}$ (non-sea-salt sulphate), $\mathrm{NH}_{4}{ }^{+}$and $\mathrm{NO}_{3}{ }^{-}$concentrations decrease from southeast to northwest. In the Canadian Arctic most soluble species' concentrations were found to be independent of elevation and accumulation. Exceptions to this included locally derived $\mathrm{Ca}^{2+}$ and $\mathrm{K}^{+}$, which had increased concentrations at higher elevations, probably caused by higher wind speeds, and the concentration of $\mathrm{SO}_{4}{ }^{2-}$, which was inversely related to accumulation rate, implying significant input by dry deposition (Sharp and others, 2002).

Lomonosovfonna is one of the highest ice fields (1255 ma.s.l.) in central Svalbard (Fig. 1). In 1997 a $121 \mathrm{~m}$ long ice core spanning $\sim 800$ years was drilled close to the highest point of the ice cap (Isaksson and others, 2001). Pohjola and others (2002a) estimated that the number of melt days in Lomonosovfonna varied from 21 to 58 days per year between 1975 and 1995 and the average melt percentage in the ice core was $30-50 \%$ (i.e. the portion of clear ice, which is assumed to be refrozen meltwater, in the ice core), but there is good evidence that isotopic and ion signals preserve an excellent record of climate and environmental variability (Pohjola and others, 2002a; Kekonen and others, 2005; Moore and others, 2005). Based on $\delta^{18} \mathrm{O}$ records in Svalbard, Isaksson and others (2003) suggest that the 20th century was the warmest during the past six centuries. Given the warm temperatures recorded in Svalbard during recent years (Głowacki and others, 2002) and the expected warming in the Arctic over the next century (Houghton and others, 2001), it is of interest to know how warm temperatures affect the preservation of the chemical stratigraphy.

The new data presented here include the most recent snow-pit study results from the Lomonosovfonna drilling site (Fig. 2). The $\mathrm{pH}$ and ion concentration data obtained during two field seasons (2001 and 2002) from six different pits are used to study variability of the concentrations and possible sources of different species. The deepest snow pit contains data from the warmest (2001) and the longest (2000) summers observed in the instrumental temperature record in the period 1978-2001 (Table 1) from the Polish Polar Station in Hornsund, southwestern Spitsbergen (Głowacki and others, 2002). Information obtained from the layers that experienced high melting is used to help interpret the ion record of the 800 year long ice core, particularly the record from the earliest years of the core that, according to our dating, would originate from the Medieval Warm Epoch (MWE) (Kekonen and others, 2005). The MWE extended from approximately the 9th to the 14th centuries (Hunt, 1998). There is still considerable uncertainty, however, concerning the duration and geographical extent of the MWE, and about how warm it was compared with the 20th century and, especially, the past few decades.

\section{STUDY SITE AND ANALYTICAL PROCEDURES}

Lomonosovfonna ice cap (Fig. 1) is around $100 \mathrm{~km}$ from Longyearbyen, the largest settlement in Svalbard (in operation since 1911) and $35 \mathrm{~km}$ from the coal-mining village, Pyramiden (in operation 1947-98). Aerosol measurements in Ny-Ålesund, northern Spitsbergen, show that during periods with warmer temperatures air masses originate from the west and have higher concentrations of sea-salt aerosols.

Table 1. Meteorological characteristics during the study periods 2000 and 2001 at Hornsund, Spitsbergen (Głowacki and others, 2002). PDD: positive degree-days; NDD: negative degree-days

\begin{tabular}{|c|c|c|c|c|c|c|}
\hline \multirow[t]{2}{*}{ Summer } & & \multirow{2}{*}{$\begin{array}{c}2000 \\
(29 \text { May-24 Oct.) }\end{array}$} & \multirow{2}{*}{$\begin{array}{c}2001 \\
\text { (9 Jun.-24 Sep.) }\end{array}$} & \multicolumn{3}{|c|}{ 1978-2001 } \\
\hline & & & & Mean & Max. & Min. \\
\hline Number of days & & 149 & 108 & 119 & 149 & 82 \\
\hline \multirow[t]{3}{*}{ Mean daily temperature $\left({ }^{\circ} \mathrm{C}\right)$} & Mean & 3.2 & 4.2 & 3.2 & 4.2 & 2.5 \\
\hline & Max. & 7.5 & 8.8 & 7.9 & 10.8 & 6.4 \\
\hline & Min. & -2.6 & -0.1 & -1.6 & 0.8 & -4.2 \\
\hline \multirow[t]{2}{*}{ Energy (deg-days) } & PDD (+) & 485.3 & 457.0 & 385.7 & 527.2 & 298.2 \\
\hline & NDD (-) & -8.8 & -0.1 & -6.1 & -20.5 & 0.0 \\
\hline Sunshine duration (hours) & & 682.1 & 312.5 & 511.4 & 705.4 & 256.0 \\
\hline
\end{tabular}




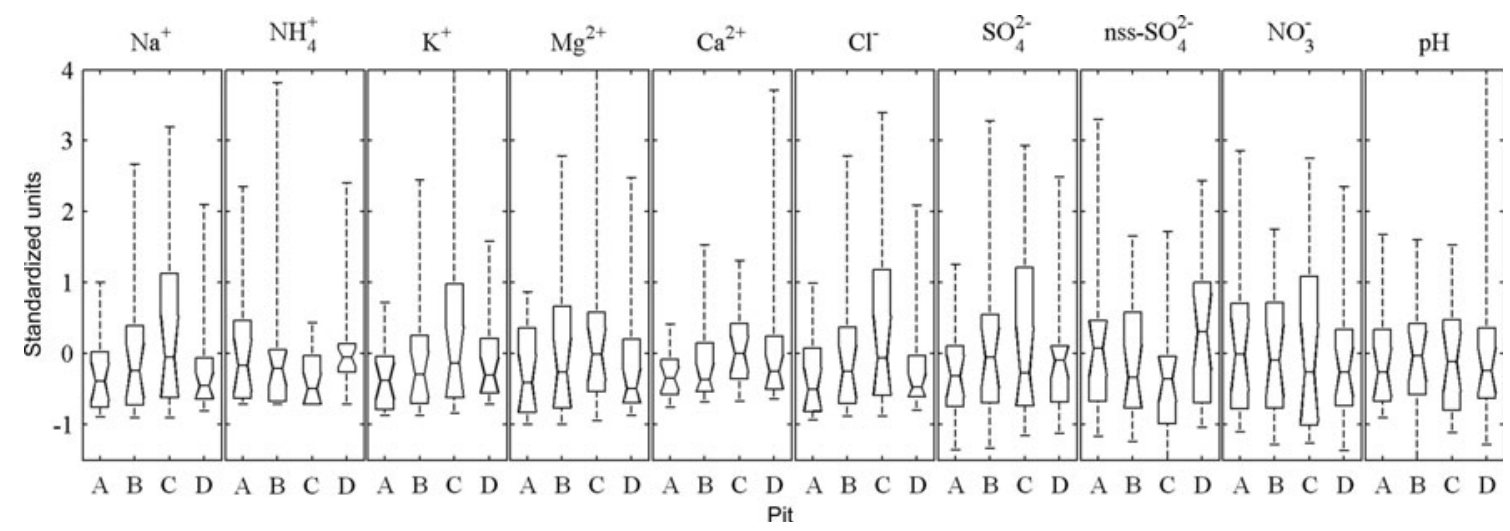

Fig. 3. Box plots of ion concentrations and $\mathrm{pH}$ of winter surface snow in pits A-D in 2002. Results are shown using standardized units. The box has lines at the lower quartile, median and upper quartile values. The whiskers are lines extending from each end of the box to show the range of the data. Notches mark the robust estimate of the uncertainty about the means for box-to-box comparison.

During periods with colder temperatures sulphate-enriched air originates from the east (Hara and others, 1997; Staebler and others, 1999). Only $14 \%$ of air masses come from the directions of local pollution sources (Niedźwiedź, 1997). According to Głowacki and Pulina (2000), Lomonosovfonna is mainly influenced by arctic-continental air masses from the Barents Sea. The cupola-shaped ice cap is surrounded by peaks with seasonal snow cover, many of which are well over $1000 \mathrm{~m}$ high, and thus local terrestrial sources, in addition to marine sources, are important for some species such as calcium (Kekonen and others, 2005).

In April 2001, samples were taken from two snow pits (pits 1 and 2), and in 2002 from four pits (pits A-D) on top of the Lomonosovfonna ice cap (Fig. 2). In addition, some fresh snow samples were collected during and after southwesterly storms in 2002. In 2003 some snow-pit sampling was also done for ion analysis on Holtedahlfonna (1195 ma.s.l.) about 50 km northeast of $\mathrm{Ny}$-Ålesund (Fig. 1).

Samples for ion analyses were taken in accordance with the ITASE (International Trans-Antarctic Scientific Expedition) protocol (Twickler and Whitlow, 1997). A clean suit, breathing mask and disposable plastic gloves were worn throughout the sampling. Once water-insoluble impurities, such as grease from fingerprints, were removed using ethanol and acetone, the sampling equipment was pre-cleaned by methods described by Jauhiainen and others (1999) and Kekonen and others (2004). The sampling wall of the snow pit was cleaned with PTFE tools and sampled continuously in $\sim 4 \mathrm{~cm}$ increments by pushing clean plastic cups into the wall. The surface from the previous summer or warm autumn was located visually during the fieldwork, as the beginning of hard layers of firn below the winter surface snow. Below the summer surface, samples were taken from pits 2, A, B and D (Fig. 2) either by cutting the samples from the wall with clean metal tools or by taking a firn core. Contamination by cleaned stainless-steel tools, which were used both during sampling and subsampling, is generally low (Jauhiainen and others, 1999). Firn cores were later sub-sampled in the cold room using the methods described by Jauhiainen and others (1999) and Kekonen and others (2004). In addition to chemical samples, snow-pit stratigraphy was studied, density measured and samples taken for other analyses.

Ion determinations were carried out using a Dionex Dx-120 suppressed ion chromatograph. The anions $\mathrm{Cl}^{-}$, $\mathrm{SO}_{4}{ }^{2-}$ and $\mathrm{NO}_{3}{ }^{-}$were determined using Dionex lonpack
AS15 columns. A total of five cations $\left(\mathrm{Na}^{+}, \mathrm{NH}_{4}{ }^{+}, \mathrm{K}^{+}, \mathrm{Mg}^{2+}\right.$ and $\mathrm{Ca}^{2+}$ ) were determined using Dionex lonpack CS12 columns. Melted samples were analyzed in random order to minimize the effects of any systematic errors. Details of the analytical methods are described by Jauhiainen and others (1999), Kekonen and others $(2002,2004)$ and Virkkunen (2004). Non-sea-salt (nss) fractions were calculated for some species $\left(\mathrm{Ca}^{2+}, \mathrm{Mg}^{2+}\right.$ and $\left.\mathrm{SO}_{4}{ }^{2-}\right)$ using sodium as the reference species.

The $\mathrm{pH}$ measurements were made according to the procedure described by Simões and Zagorodnov (2001) using a Radiometer XC161 pH electrode. Replicate measurements were conducted for each sample, and based on these measurements the random error is $<1.5 \%$.

\section{RESULTS}

Surface snow samples, i.e. the snow above the last summer surface, span the time period from the time of sampling (April) to autumn of the previous year. The snow pits on the Lomonosovfonna ice field (Fig. 2) are spread over $\sim 300 \mathrm{~m}$ horizontally around the summit, allowing the spatial variability of different species to be studied. Figure 2 also shows that the pits come from approximately the same elevation. Mean concentrations $(\bar{x})$, standard deviations $(\sigma)$ and the coefficient of variation $(\mathrm{CV}=\sigma / \bar{x})$ in snow pits sampled on Lomonosovfonna and Holtedahlfonna are presented in Table 2. To ensure that comparison is between the same snow layers in pits A-D, results from some fresh snow layers were excluded from pits $C$ and $D$ because this snow was deposited after pits A and B were sampled. The data are essentially log-normally distributed and there are no significant differences in concentration between pits A-D. Ion concentrations and $\mathrm{pH}$ are also shown as box plots in Figure 3, indicating there is no significant difference in the sample means, though the ranges vary substantially. The CV shows some differences in the variability of the species on Lomonosovfonna. $\mathrm{H}^{+}, \mathrm{NO}_{3}{ }^{-}$and $\mathrm{SO}_{4}{ }^{2-}$ have the lowest $\mathrm{CV}$ values while the values for $\mathrm{Na}^{+}, \mathrm{Cl}^{-}, \mathrm{K}^{+}, \mathrm{Mg}^{2+}$ and $\mathrm{Ca}^{2+}$ are closer to unity. The $\mathrm{nssCa}^{2+}$ and $\mathrm{NH}_{4}{ }^{+}$species show the largest variability. We also calculated $\mathrm{CV}$ values for a snow pit sampled in Holtedahlfonna in 2003 and for aerosol measurements at Zeppelin research station in 2001 to show that CV depends on the arriving air masses and reflects the distribution of ions in the atmosphere. 
Table 2. Mean concentrations $(\bar{x})$, standard deviations $(\sigma)$ in $\mu \mathrm{Eq} \mathrm{L}^{-1}$, and the coefficient of variation, $\mathrm{CV}$, in winter surface snow in different pits sampled on Lomonosovfonna in 2002 (pits A-D), in 2001 (pits 1 and 2) and on Holtedahlfonna in 2003. Outliers were included in the calculations. The table also contains the results of aerosol measurements in $\mathrm{ng} \mathrm{m}^{-3}$ at Zeppelin research station during the 'dark' campaign in 2001 (Teinilä and others, 2004) and the CV values calculated based on these results

\begin{tabular}{|c|c|c|c|c|c|c|c|c|c|c|c|c|}
\hline & \multicolumn{3}{|c|}{ Pit $\mathrm{A}(n=21)$} & \multicolumn{3}{|c|}{ Pit B $(n=21)$} & \multicolumn{3}{|c|}{ Pit C $(n=22)$} & \multicolumn{3}{|c|}{ Pit D $(n=24)$} \\
\hline & $\bar{x}$ & $\sigma$ & $\mathrm{CV}$ & $\bar{x}$ & $\sigma$ & $\mathrm{CV}$ & $\bar{x}$ & $\sigma$ & $\mathrm{CV}$ & $\bar{x}$ & $\sigma$ & $\mathrm{CV}$ \\
\hline $\mathrm{Na}^{+}$ & 12.81 & 10.59 & 0.83 & 20.16 & 20.46 & 1.02 & 27.3 & 26.63 & 0.98 & 15.96 & 15.91 & 1.00 \\
\hline $\mathrm{NH}_{4}^{+}$ & 0.24 & 0.27 & 1.09 & 0.19 & 0.30 & 1.60 & 0.17 & 0.37 & 2.14 & 0.27 & 0.30 & 1.10 \\
\hline $\mathrm{K}^{+}$ & 0.28 & 0.22 & 0.81 & 0.43 & 0.42 & 1.00 & 0.64 & 0.71 & 1.12 & 0.40 & 0.31 & 0.77 \\
\hline $\mathrm{Mg}^{2+}$ & 2.75 & 2.16 & 0.79 & 3.86 & 3.50 & 0.91 & 5.04 & 4.67 & 0.93 & 3.19 & 2.92 & 0.92 \\
\hline $\mathrm{Ca}^{2+}$ & 0.70 & 0.51 & 0.73 & 0.93 & 0.85 & 0.92 & 1.37 & 0.96 & 0.71 & 1.59 & 2.58 & 1.63 \\
\hline $\mathrm{nssCa}^{2+}$ & 0.14 & 0.32 & 2.33 & 0.04 & 0.33 & 8.35 & 0.17 & 0.70 & 4.19 & 0.88 & 2.55 & 2.88 \\
\hline $\mathrm{Cl}^{-}$ & 14.60 & 12.25 & 0.84 & 23.15 & 23.36 & 1.01 & 30.9 & 29.92 & 0.97 & 18.55 & 18.54 & 1.00 \\
\hline $\mathrm{SO}_{4}^{2-}$ & 3.58 & 1.79 & 0.50 & 4.38 & 2.80 & 0.64 & 4.74 & 2.97 & 0.63 & 4.25 & 2.30 & 0.54 \\
\hline $\mathrm{nssSO}_{4}{ }^{2-}$ & 2.03 & 1.15 & 0.57 & 1.94 & 1.06 & 0.55 & 1.44 & 1.24 & 0.86 & 2.32 & 1.23 & 0.53 \\
\hline $\mathrm{NO}_{3}{ }^{-}$ & 1.25 & 0.70 & 0.56 & 1.23 & 0.61 & 0.50 & 1.27 & 0.87 & 0.69 & 1.15 & 0.61 & 0.53 \\
\hline \multirow[t]{2}{*}{$\mathrm{H}^{+}$} & 4.00 & 0.69 & 0.17 & 3.98 & 0.76 & 0.19 & 4.00 & 0.79 & 0.20 & 3.89 & 1.11 & 0.29 \\
\hline & \multicolumn{3}{|c|}{ Pit $1(n=33)$} & \multicolumn{3}{|c|}{ Pit $2(n=30)$} & \multicolumn{3}{|c|}{ Holtedahlfonna $(n=29)$} & \multicolumn{3}{|c|}{ Zeppelin $(n=9)$} \\
\hline $\mathrm{Na}^{+}$ & 9.26 & 8.04 & 0.87 & 12.86 & 11.45 & 0.89 & 18.60 & 26.14 & 1.41 & 245 & 174 & 0.71 \\
\hline $\mathrm{NH}_{4}^{+}$ & 0.69 & 0.69 & 0.99 & 0.49 & 0.48 & 0.97 & 0.95 & 1.31 & 1.37 & 69 & 53 & 0.77 \\
\hline $\mathrm{K}^{+}$ & 0.22 & 0.17 & 0.76 & 0.29 & 0.24 & 0.83 & 0.44 & 0.57 & 1.28 & - & - & - \\
\hline $\mathrm{Mg}^{2+}$ & 2.27 & 1.93 & 0.85 & 2.92 & 2.49 & 0.85 & 4.16 & 5.57 & 1.34 & - & - & - \\
\hline $\mathrm{Ca}^{2+}$ & 2.21 & 3.70 & 1.67 & 0.91 & 0.54 & 0.60 & 1.66 & 2.13 & 1.28 & - & - & - \\
\hline $\mathrm{nssCa}^{2+}$ & 1.80 & 3.54 & 1.97 & 0.34 & 0.25 & 0.74 & 0.85 & 1.93 & 2.29 & 7.5 & 4.5 & 0.60 \\
\hline $\mathrm{Cl}^{-}$ & 10.65 & 9.06 & 0.85 & 15.23 & 13.66 & 0.90 & 22.06 & 31.30 & 1.42 & 357 & 283 & 0.79 \\
\hline $\mathrm{SO}_{4}^{2-}$ & 4.46 & 1.89 & 0.42 & 4.71 & 2.16 & 0.46 & 6.29 & 6.16 & 0.98 & - & - & - \\
\hline $\mathrm{nssSO}_{4}{ }^{2-}$ & 3.34 & 1.54 & 0.46 & 3.15 & 1.37 & 0.43 & 4.04 & 4.02 & 0.99 & 849 & 509 & 0.60 \\
\hline $\mathrm{NO}_{3}{ }^{-}$ & 1.72 & 0.79 & 0.46 & 1.70 & 0.80 & 0.47 & 2.81 & 4.12 & 1.47 & 41 & 42 & 1.02 \\
\hline $\mathrm{H}^{+}$ & - & - & - & - & - & - & 6.53 & 6.58 & 1.01 & - & - & - \\
\hline
\end{tabular}

Arctic haze was studied by comparing winter surface snow data from Lomonosovfonna (2001 and 2002) and Holtedahlfonna (2003) (Fig. 4). Although the pits come from different years, there are very clear differences between them, and we will show these are unlikely to be simply a result of interannual variability. In the Holtedahlfonna winter snow, an obvious spike in concentrations of sulphate, nitrate and ammonium and a simultaneous minimum in $\mathrm{pH}$ can be seen. In Lomonosovfonna, however, no such events were found in any of the six pits, as shown, for example, in pit D (Fig. 4). Further, the CV values show that air masses arriving at these two locations are different.

Some of the pits were sampled below the summer surface. The deepest of the snow pits, pit A, was $3.27 \mathrm{~m}$ deep and probably spans several years, including some years with unusual melting. Heavy melting here describes melting that elutes an unusually large portion of the ions from the snowpack and spans a long time period in the snowpack. Dating of the pit (described later) is necessary in order to study the post-depositional changes of ion concentrations caused by melting. Elution factors (e) were calculated for each ion species similarly to Moore and others (2005), but by comparing the same layer of snow before and after the melting period as $e=1-\exp \left(\overline{\log C_{\mathrm{b}}}-\overline{\log C_{\mathrm{s}}}\right)$, where $\log$ is the natural logarithm, the bar implies the mean over the species, $C_{\mathrm{s}}$ is the particular species concentration in the surface snowpack in 2001 with no melting and $C_{b}$ is the concentration in the layers of pit A from autumn 2001 to autumn 2000, where the snow had experienced melting. Two sets of elution factors for surface snow were calculated using the data from both pits sampled in 2001 (Table 3). In the 1997 ice core the elution factors are calculated based on the assumption that, during melting, ions elute from the snowpack and form clear-ice layers as the water refreezes. When we consider the possibility that not all the bubbly layers have experienced melting, elution factors are similar to other records, i.e. during melting, divalent ions and nitrate elute more easily than other ions and there is more melting in the snow pits than in the ice-core record.

The concentration ratio of two ionic species in a sample has been proposed as a melt indicator by lizuka and others (2002) using a Svalbard ice core from Austfonna (Fig. 1). Grinsted and others (2006) developed a model of melting effects on ion concentrations, and showed that it is the logarithm of the ratios rather than the ratios themselves that is proportional to melt. A good melt indicator should have several properties: species need to have different elution rates and they should come mainly from the same source. Additionally, the ratio used as the melt indicator should be relatively constant in dry snow and should be spatially and interannually stable. Elution factors are used for estimating the elution rates of different ions, and $\mathrm{CV}$ describes the variability of the species. Finally, the melt indicator must have clearly different values in the melt layers and in dry snow. Sodium and chloride both originate mostly from sea water but their elution rates are very similar and thus $\log \left(\left[\mathrm{Na}^{+}\right] /\left[\mathrm{Cl}^{-}\right]\right)$, where [ ] denotes the concentrations in $\mu \mathrm{EqL}^{-1}$, is too constant to use. Neither $\log \left(\left[\mathrm{Na}^{+}\right] /\left[\mathrm{Ca}^{2+}\right]\right)$ nor $\log \left(\left[\mathrm{Na}^{+}\right] /\left[\mathrm{K}^{+}\right]\right)$are suitable indicators since both calcium and potassium may have high non-sea-salt peaks, 
so the value is not necessarily constant, even in dry snow. Lomonosovfonna is affected by sulphate-enriched air masses, and a significant part of the sulphate comes from sources other than sea salt $\left(36-75 \%\right.$ of $\mathrm{SO}_{4}{ }^{2-}$ in the winter surface snow), so $\log \left(\left[\mathrm{Na}^{+}\right] /\left[\mathrm{SO}_{4}{ }^{2-}\right]\right)$ is not very useful. The best melt indicator in Lomonosovfonna is $\log \left(\left[\mathrm{Na}^{+}\right] /\right.$ $\left.\left[\mathrm{Mg}^{2+}\right]\right)$; this was also the conclusion of lizuka and others (2002) for Austfonna. These two ions have very different elution rates as can be seen in Table 3. Also $\mathrm{pH}$ shows significant differences ( $t$ test, $p<0.05$ ) in surface snow $(\mathrm{pH} \sim 5.4)$ and in melt layers $(\mathrm{pH} \sim 5.6)$, indicating that some of the hydrogen ions are lost by percolation or runoff. As shown below, the $\mathrm{H}^{+}$concentration is stable both annually and interannually in the winter surface snow and thus $\mathrm{pH}$ is a useful melt indicator on Lomonosovfonna. This may not, however, apply to glaciers such as Holtedahlfonna where there are Arctic-haze signatures and $\mathrm{pH}$ can vary greatly in dry snow.

Results obtained from the melt layers in the snow pits are then used to interpret the 1997 ice core. We compare these records and find some periods with similar signatures of melting: low concentrations of divalent ions and nitrate and high values of melt indicator, $\log \left(\left[\mathrm{Na}^{+}\right] /\left[\mathrm{Mg}^{2+}\right]\right)$. This interpretation is tested using a Monte Carlo method (described later), and the same melting periods that were located visually are found at significance levels of $99 \%$ and $99.9 \%$.

\section{DISCUSSION}

\section{Spatial variations}

Radar measurements (Fig. 2) show that pits A-D are located in similar accumulation rate areas, with only pit $\mathrm{A}$ in an area of slightly lower accumulation. Consistent results were also obtained by comparing the separation (in water equivalent) of certain distinct features (shown by arrows in Fig. 5) in the nitrate profiles from each of the pits A-D. The accumulation at pit $A$ over the short period spanned by the nitrate peaks is about $10 \%$ lower than in the other pits. The radar data suggest that the lower-accumulation signature is probably representative of the lower accumulation to the east of the central summit area. This is most likely a result of wind direction during the winter, suggesting dominant easterly winds, consistent with the analysis of synoptic barometric maps made by Niedźwiedź (1997). Since the ice cap is

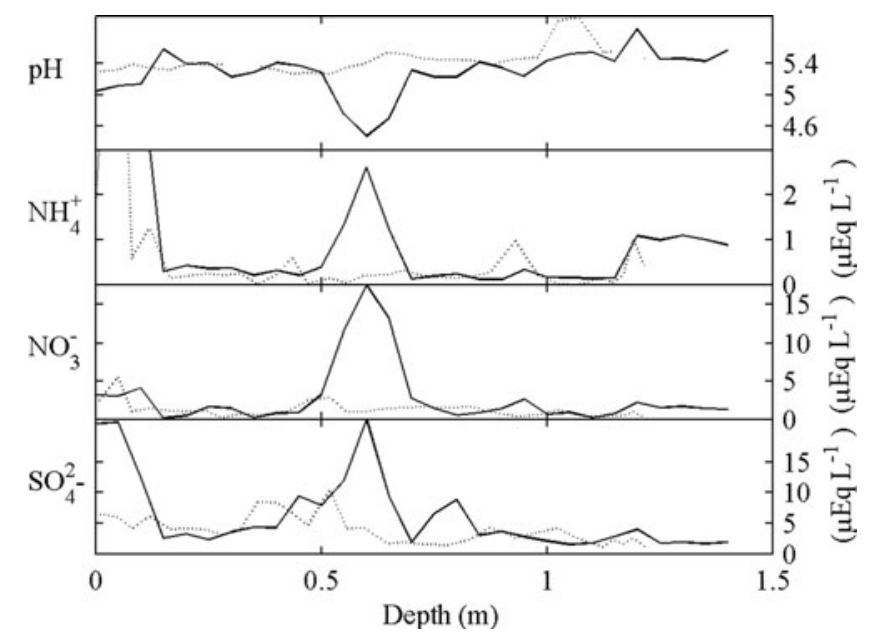

Fig. 4. Chemical concentrations and $\mathrm{pH}$ in winter snow from Holtedahlfonna in 2003 (solid curve) and Lomonosovfonna in 2002 in pit $\mathrm{D}$ (dotted curve). The feature at $0.6 \mathrm{~m}$ in Holtedahlfonna has a clear Arctic-haze signature that is not seen on Lomonosovfonna.

cupola-shaped (Fig. 2), this accumulation pattern cannot be a steady-state situation unless the higher accumulation on the west side of the ice cap is compensated for by greater ice flux to the west, or by higher ablation on the west side of the dome during summer, which is to be expected considering the summer diurnal temperature cycle.

Some explanations for the variability of species can be inferred from the coefficient of variation values in pits $A-D$ (Table 2; similar CV values were also found in pits 1 and 2 sampled in 2001). The CV is higher if a species is not homogeneously distributed in the atmosphere. $\mathrm{H}^{+}$has the lowest $\mathrm{CV}$, which means that it is not very variable in the snow. Głowacki and Pulina (2000) also observed that the variation of $\mathrm{pH}$ over the whole winter season 1990/91 was small in Lomonosovfonna snow. Moreover, the average $\mathrm{pH}$ they found was the same as in our study (5.4), which also implies that the interannual variation of $\mathrm{H}^{+}$concentration is not very great at present. Nitrate and sulphate have $C V$ values slightly higher $(0.42-0.69)$ than $\mathrm{H}^{+}$. They are considered to be mostly gaseous species in the atmosphere (Hewitt and Sturges, 1993) and after long-range transportation they are well mixed in the air mass, so they also have low variability

Table 3. Elution factors (e) for ion species in the snow pits ( $\mathrm{P} 1$ and $\mathrm{P} 2$ denoting pits 1 and 2, respectively) and in the 1997 ice core (C) (Moore and others, 2005). $\mathrm{C}_{\text {mod }}$ takes into account that not all the bubbly layers have necessarily experienced melting in the 1997 Lomonosovfonna ice-core record. Elution factors for Austfonna glacier in 1998, e(A), were calculated based on the concentrations in wet and dry snow (lizuka and others, 2002)

\begin{tabular}{|c|c|c|c|c|c|c|c|c|}
\hline$e(\mathrm{P} 1)$ & $\begin{array}{l}\mathrm{NH}_{4}{ }^{+} \\
0.18\end{array}$ & $\begin{array}{l}\mathrm{Na}^{+} \\
0.49\end{array}$ & $\begin{array}{l}\mathrm{Cl}^{-} \\
0.58\end{array}$ & $\begin{array}{l}\mathrm{K}^{+} \\
0.70\end{array}$ & $\begin{array}{l}\mathrm{NO}_{3}{ }^{-} \\
0.85\end{array}$ & $\begin{array}{l}\mathrm{Mg}^{2+} \\
0.86\end{array}$ & $\begin{array}{l}\mathrm{Ca}^{2+} \\
0.88\end{array}$ & $\begin{array}{l}\mathrm{SO}_{4}{ }^{2-} \\
0.88\end{array}$ \\
\hline$e(\mathrm{P} 2)$ & $\begin{array}{l}\mathrm{NH}_{4}{ }^{+} \\
-0.29\end{array}$ & $\begin{array}{l}\mathrm{Na}^{+} \\
0.66\end{array}$ & $\begin{array}{l}\mathrm{Cl}^{-} \\
0.72\end{array}$ & $\begin{array}{l}\mathrm{K}^{+} \\
0.76\end{array}$ & $\begin{array}{l}\mathrm{Ca}^{2+} \\
0.81\end{array}$ & $\begin{array}{l}\mathrm{NO}_{3}{ }^{-} \\
0.85\end{array}$ & $\begin{array}{l}\mathrm{SO}_{4}{ }^{2-} \\
0.89\end{array}$ & $\begin{array}{l}\mathrm{Mg}^{2+} \\
0.90\end{array}$ \\
\hline$e(C)$ & $\begin{array}{l}\mathrm{Mg}^{2+} \\
0.27\end{array}$ & $\begin{array}{l}\mathrm{NH}_{4}{ }^{+} \\
0.28\end{array}$ & $\begin{array}{l}\mathrm{Na}^{+} \\
0.28\end{array}$ & $\begin{array}{l}\mathrm{Cl}^{-} \\
0.31\end{array}$ & $\begin{array}{l}\mathrm{K}^{+} \\
0.35\end{array}$ & $\begin{array}{l}\mathrm{Ca}^{2+} \\
0.37\end{array}$ & $\begin{array}{l}\mathrm{SO}_{4}{ }^{2-} \\
0.43\end{array}$ & $\begin{array}{l}\mathrm{NO}_{3}{ }^{-} \\
0.47\end{array}$ \\
\hline$e\left(\mathrm{C}_{\bmod }\right)$ & $\begin{array}{l}\mathrm{NH}_{4}{ }^{+} \\
0.25\end{array}$ & $\begin{array}{l}\mathrm{K}^{+} \\
0.36\end{array}$ & $\begin{array}{l}\mathrm{Na}^{+} \\
0.43\end{array}$ & $\begin{array}{l}\mathrm{Cl}^{-} \\
0.44\end{array}$ & $\begin{array}{l}\mathrm{Ca}^{2+} \\
0.51\end{array}$ & $\begin{array}{l}\mathrm{Mg}^{2+} \\
0.56\end{array}$ & $\begin{array}{l}\mathrm{NO}_{3}{ }^{-} \\
0.61\end{array}$ & $\begin{array}{l}\mathrm{SO}_{4}{ }^{2-} \\
0.61\end{array}$ \\
\hline$e(\mathrm{~A})$ & $\begin{array}{l}\mathrm{NH}_{4}^{+} \\
0.37\end{array}$ & $\begin{array}{l}\mathrm{K}^{+} \\
0.71\end{array}$ & $\begin{array}{l}\mathrm{Na}^{+} \\
0.73\end{array}$ & $\begin{array}{l}\mathrm{Cl}^{-} \\
0.75\end{array}$ & $\begin{array}{l}\mathrm{Ca}^{2+} \\
0.77\end{array}$ & $\begin{array}{l}\mathrm{NO}_{3}{ }^{-} \\
0.79\end{array}$ & $\begin{array}{l}\mathrm{SO}_{4}{ }^{2-} \\
0.88\end{array}$ & $\begin{array}{l}\mathrm{Mg}^{2+} \\
0.93\end{array}$ \\
\hline
\end{tabular}




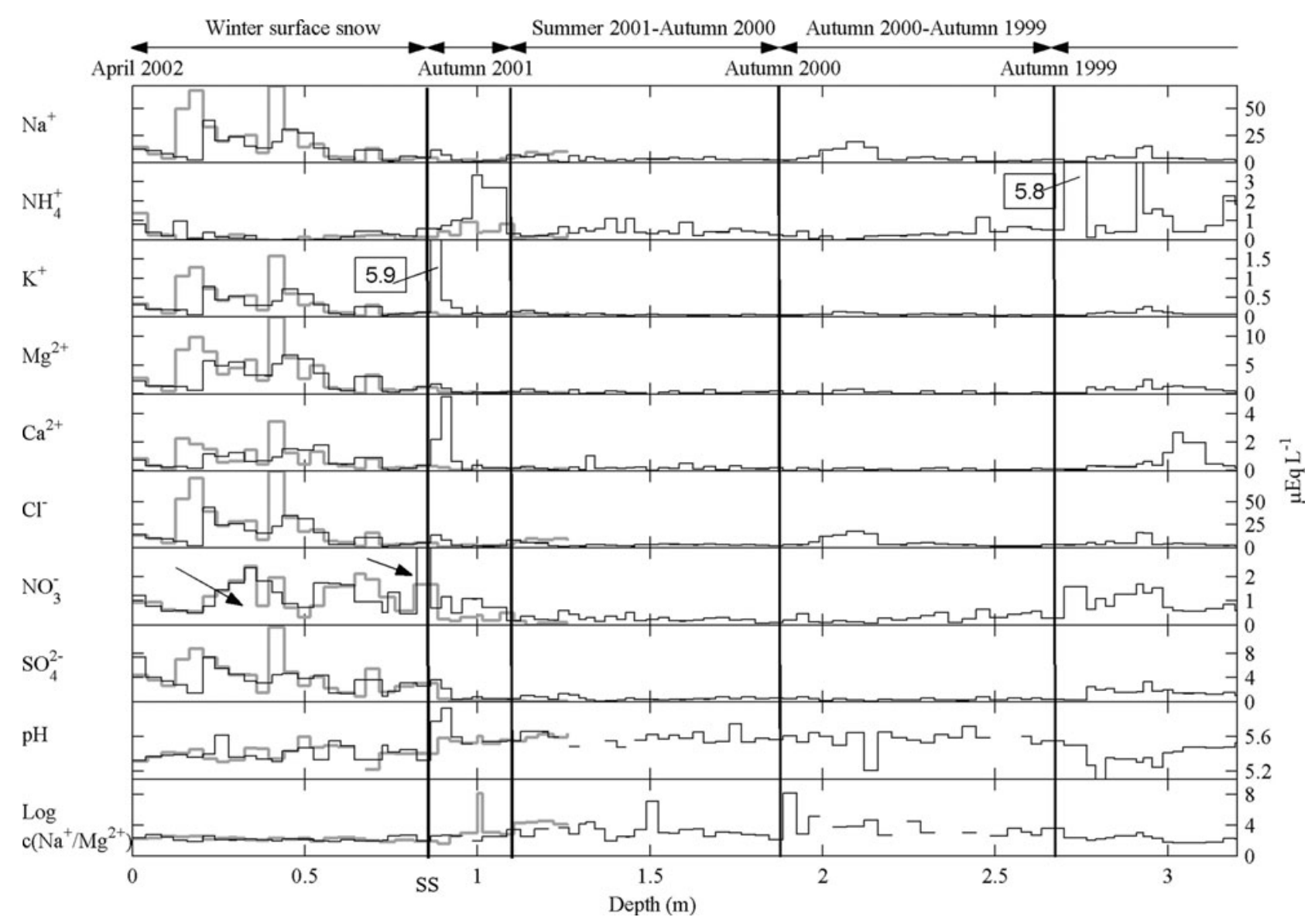

Fig. 5. Ion concentration, $\mathrm{pH}$ and melt indicator profiles used in dating pit $\mathrm{A}$. The concentrations in pit $\mathrm{B}$ are shown for comparison (thick grey histogram). Arrows in the $\mathrm{NO}_{3}{ }^{-}$profile show features (wide cluster of peaks and a single high-concentration peak) also seen in pits $\mathrm{C}$ and D. Winter surface snow is above the visually observed summer surface (SS). Below it is the autumn 2001 layer, which has high concentrations of typical autumn species $\left(\mathrm{NH}_{4}{ }^{+}, \mathrm{K}^{+}\right.$and $\left.\mathrm{Ca}^{2+}\right)$. Firn from autumn 2001 to autumn 1999 has experienced heavy melting during the summers of 2000 and 2001, and thus has very low ion concentrations and high melt-indicator, $\log \left(\left[\mathrm{Na}^{+}\right] /\left[\mathrm{Mg}^{2+}\right]\right)$, values. Autumn 2000 is roughly estimated to be at depth $1.85 \mathrm{~m}$ based on density measurements in snow pits in 2001 . At 2.6-2.7 m depth the concentrations increase again and melt indicators have values similar to the winter surface snow denoting the beginning of autumn 1999 layers.

in the snowpack. Ions associated with aerosols mostly derived from the sea, such as sodium, chloride and magnesium (Kekonen and others, 2005), have values closer to unity. These ions are not so well mixed in the atmosphere as more gaseous species but, since the Lomonosovfonna ice field is away from the coast, the aerosol is quite well mixed and the largest particles have already been deposited during transportation (Teinilä and others, 2004). The CV of nssCa ${ }^{2+}$ has the highest values (2.33-8.35), a sign of high variability in the air. Table 2 shows that $\mathrm{nssCa}^{2+}$ concentrations in winter snow are only $4-55 \%$ of total $\mathrm{Ca}^{2+}$, whereas for the Lomonosovfonna ice core $80 \%$ of $\mathrm{Ca}^{2+}$ was from non-seasalt sources (Kekonen and others, 2005). The most likely nonsea-salt source is terrestrial dust derived from local rocks, which are partially snow-covered during winter. Dust is not very evenly mixed in the air because the particle size is large and transportation paths from the sources are relatively short. The snow pits demonstrate this, as high-concentration $\mathrm{nssCa}^{2+}$ peaks can be found in some, but not all, pits. For example, Figure 5 shows a high $\mathrm{Ca}^{2+}$ peak in the autumn 2001 snow in the pit A record, while the concentration in pit $B$ is rather low. This high-concentration peak mostly consists of the non-sea-salt fraction of calcium.

The $\mathrm{CV}$ of $\mathrm{NH}_{4}{ }^{+}$in Lomonosovfonna winter surface snow is $0.97-2.14$ (Table 2). This suggests that, surprisingly, the ammonium ion is not a gaseous species but rather a particulate and heterogeneously distributed ion. This implies that the ammonium ion, which has a relatively short residence time in the atmosphere (Hansson and Holmén, 2001), has reacted to form a particulate species. Ammonia gas $\left(\mathrm{NH}_{3}\right)$ is often stabilized by reactions with sulphur dioxide $\left(\mathrm{SO}_{2}\right)$ and nitrogen oxides $\left(\mathrm{NO}_{\mathrm{x}}\right)$, resulting in the formation of ammonium nitrate $\left(\mathrm{NH}_{4} \mathrm{NO}_{3}\right)$ and ammonium sulphates $\left(\mathrm{NH}_{4} \mathrm{HSO}_{4}\right.$ and $\left.\left(\mathrm{NH}_{4}\right)_{2} \mathrm{SO}_{4}\right)$, which are important constituents of fine-particulate matter (Battye and others, 2003). In the snow pits sampled in 2001, ammonium correlates significantly $(p \leq 0.05)$ with nitrate while in 2002 there are no significant correlations between the two species. Kekonen and others (2002) also found that the correlation between $\mathrm{NH}_{4}{ }^{+}$and $\mathrm{NO}_{3}{ }^{-}$varied greatly in the Lomonosovfonna ice core during the last 100 years. Significant correlations were found before the growth of anthropogenic nitrate emissions in the mid-20th century, which implies that ammonium nitrate has significant natural sources or has formed by in situ reactions in the ice. Jickells and others (2003) show that there is a marine source of aerosol ammonium, which could provide a winter source to the ice cap when the emissions from the major natural sources (e.g. large forest fires in the Northern Hemisphere) are at their lowest (Hansson and Holmén, 2001). 
The CV values, however, also depend on the arriving air masses. For example, in the snow pit sampled in Holtedahlfonna in 2003 the mean ion concentrations are of similar magnitude to those in the Lomonosovfonna ice core (except for the species affected during Arctic-haze episodes: $\mathrm{H}^{+}$, $\mathrm{NH}_{4}{ }^{+}, \mathrm{NO}_{3}{ }^{-}$and $\mathrm{SO}_{4}{ }^{2-}$ ), but the $\mathrm{CV}$ values of the marine species $\left(\mathrm{Cl}^{-}, \mathrm{Na}^{+}, \mathrm{K}^{+}, \mathrm{Mg}^{2+}\right)$ are all higher. Thus, the Holtedahlfonna air masses most probably transport aerosol of larger particle size. For sea-salt species, such as sodium and chloride, this could be caused by the marine air arriving more directly to this location than to Lomonosovfonna, as the Holtedahlfonna ice cap is close to the western coast of Spitsbergen (Fig. 1). Also the behaviour of $\mathrm{H}^{+}, \mathrm{NH}_{4}{ }^{+}, \mathrm{NO}_{3}{ }^{-}$ and $\mathrm{SO}_{4}{ }^{2-}$ is quite different; all of them correlate significantly with each other $(p \leq 0.05)$ and the mean concentrations are much higher than at Lomonosovfonna. Figure 4 shows that these species reach high concentrations and low $\mathrm{pH}$ simultaneously in the late winter snow in Holtedahlfonna, which clearly denotes Arctic haze. In contrast, there are no traces of Arctic haze on Lomonosovfonna in the winter of 2001/02 (Figs 4 and 5) or in the ice core. Even though the snow pits on Lomonosovfonna were sampled during different years, there is reason to believe that there was Arctic haze over Holtedahlfonna in the spring of 2001 and 2002 in addition to 2003, since Arctic haze has been a recurring phenomenon every winter and spring since it was first discovered. The elevation difference between Lomonosovfonna and Holtedahlfonna is only $\sim 60 \mathrm{~m}$, so simple elevation is not the reason for the absence of Arctic haze on Lomonosovfonna. Other local geographical and meteorological factors, such as the proximity of deep fjords and their orientation relative to air-mass movement, may influence the occurrence of Arctic haze in these two locations.

In 2001, air samples were collected close to Ny-Ålesund at $470 \mathrm{~m}$ a.s.I. (Zeppelin Mountain) and at sea level during 'dark' and 'light' campaigns (Teinilä and others, 2004). Based on the results obtained during the dark campaign at the Zeppelin station we calculated the CV values for the species available (Table 2). This campaign was chosen because it best resembles the conditions at Holtedahlfonna glacier, where the sampled snowpack is mainly formed during the dark period of the year and is at high elevation. The CV values of the two sites representing the composition of the air (Zeppelin station) and snow (Holtedahlfonna) are very similar. The order of increasing $\mathrm{CV}$ values in both of the records is: $\mathrm{nsSSO}_{4}{ }^{2-}$, group of three species $\left(\mathrm{Na}^{+}, \mathrm{Cl}^{-}\right.$and $\mathrm{NH}_{4}{ }^{+}$) and $\mathrm{NO}_{3}{ }^{-}$. Thus we can say that $\mathrm{CV}$ values of the snowpack not only describe the distribution of different species in snow, which could also be caused by, for example, wind reworking of snow after deposition, but also reflect the distribution of ions in the atmosphere.

\section{Temporal variations}

To study post-depositional changes of ion concentrations caused by melting on Lomonosovfonna we dated the deepest (3.27 m) snow pit (Fig. 5), pit A, using the chemical and physical stratigraphy of the pit together with instrumental meteorological records of 1999-2002. The summers of 2000 and 2001 were exceptionally warm in Hornsund: summer 2000 was the longest, and summer 2001 had the highest mean daily temperature over the period 1978-2001 (Głowacki and others, 2002). Summer is defined here as a period with mean daily temperature above zero. Thus it is likely that the snowpack on Lomonosovfonna suffered extensive melting during those summers.

\section{Spring 2002 to autumn 2001}

During the fieldwork in spring 2002 the summer surface (SS) was located at a snow depth of $0.86 \mathrm{~m}$, denoting the autumn 2001 layer. The winter snow above contains $\mathrm{SO}_{4}{ }^{2-}, \mathrm{NO}_{3}{ }^{-}$ and sea-salt species at relatively high concentrations, $\mathrm{NH}_{4}{ }^{+}$ concentration is low and $\mathrm{pH}$ is $\sim 5.4$. At a depth of $\sim 1.1 \mathrm{~m}$ there is a $1 \mathrm{~cm}$ thick depth-hoar layer, which separates the summer and autumn layers of 2001. The autumn snow was deposited on the glacier after the summer melt period and thus the concentrations of all ions are higher than in the melt layers below it. This autumn layer seems to be rather thick, but, at least in Hornsund, the highest precipitation in 2001 was in August to September. In addition, calcium, ammonium and potassium, which are expected to peak in the autumn and/or late summer, have higher concentrations.

\section{Autumn 2001 to autumn 1999}

Below the autumn 2001 layer the ion concentrations are very low and $\mathrm{pH}$ rises to $\sim 5.6$, indicating runoff or deeper percolation of ions. Two snow pits were sampled in 2001 and thus we know that the snow was precipitated with much higher concentrations. The melt indicator, $\log \left(\left[\mathrm{Na}^{+}\right] /\right.$ $\left.\left[\mathrm{Mg}^{2+}\right]\right)$, is also different from that in the winter surface snow. The layer spanning autumn 2001 to autumn 2000 was estimated to be roughly $0.9 \mathrm{~m}$ thick, based on the density data of spring 2001 snow pits. Below this autumn 2001 to autumn 2000 layer, the concentrations remain low for another $0.7-0.8 \mathrm{~m}$. At $2.1 \mathrm{~m}$ depth the sea-salt species, especially sodium and chloride, reach slightly higher concentrations while ammonium concentration is close to zero, which both imply winter deposition.

In 2001 we drilled a short firn core below the summer surface in pit 2; this core represents the concentrations in the snowpack after the long summer of 2000 but has no effects from the 2001 summer. We tied this section to the pit A ion record (which contains layers affected by both 2000 and 2001 summers) at 2-2.4 m depth by comparing the $\mathrm{Na}^{+}, \mathrm{Cl}^{-}$ and $\mathrm{K}^{+}$concentration profiles (Fig. 6). These ions have low elution factors (Table 3). However, all the other ions, including $\mathrm{H}^{+}$, have lower concentrations in pit $\mathrm{A}$ than in pit 2, which means that these species were much more affected by the unusually warm summer of 2001 than the long summer of 2000. The melt indicator, $\log \left(\left[\mathrm{Na}^{+}\right] /\right.$ $\left.\left[\mathrm{Mg}^{2+}\right]\right)$, also had lower values after the long summer than after the warm summer. These results indicate that air temperature is a more important factor controlling the elution than the length of the summer, duration of sunshine or number of positive degree-days, which all were greater during summer 2000 than summer 2001. This is consistent with some melting models where runoff increases linearly as a function of air temperature (e.g. Zhang and others, 2007).

Melting starts at the surface of the snowpack, and the ion concentrations of this first portion of meltwater, also called the ionic pulse, can be high. Once melting has been initiated, the meltwater usually flows in preferential pathways through the snowpack and bypasses many individual snow grains, which then retain their solute load (Bales and others, 1993). The lower concentrations in the meltwater after the ionic pulse are probably due to the dilution by flow of water along preferred pore channels from the top to the bottom of the snowpack. Thus, as Bales and others (1993) 


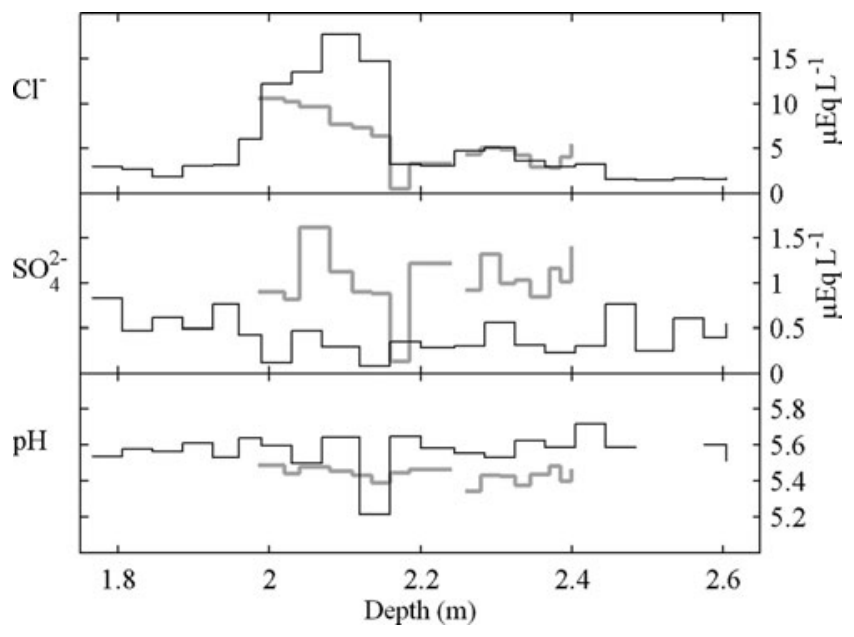

Fig. 6. A short firn core was sampled below the summer surface in pit 2 in 2001 (grey histogram) that is only affected by the long summer of 2000. The depth of this core was scaled to match the depth scale of the pit A ion record. The pit A record shown (black histogram) was affected by both the long and warm summers (2000 and 2001, respectively). Chloride concentration has not significantly changed due to the warm summer of 2001 but the concentrations of more easily eluted species, such as $\mathrm{SO}_{4}{ }^{2-}$ and $\mathrm{H}^{+}$, show greater elution in the pit $\mathrm{A}$ record.

have shown, the snow in the middle of the snowpack is not as sensitive to elution as the surface snow. In pit A, however, the concentrations were low throughout the layer spanning two years, which means that melting was exceptionally strong during summer 2001.

\section{Autumn 1999 to bottom of the pit}

After the low-concentration layers the ion concentrations increase. Ammonium is known to reach its highest concentration in late summer or winter (Hansson and Holmén, 2001) and thus we interpret the peak in $\mathrm{NH}_{4}{ }^{+}$as autumn 1999 and place the end of the 2000 melt season at 2.6$2.7 \mathrm{~m}$. Also, the melt indicators start to reach values typical of surface snow, ion concentrations get higher and $\mathrm{pH}$ is lower, denoting the end of autumn of 1999. High concentrations of ammonium and calcium also imply autumn. In addition, at 3.17-3.20 $\mathrm{m}$ there is a depth-hoar layer possibly separating the autumn and summer layers of 1999. Although the autumn layer appears to be relatively thick, there was a lot of snow that autumn according to Hornsund precipitation data.

Goto-Azuma and others (2002) found that ion concentrations increased below layers with low concentrations, similarly to our pit A ion record. They concluded that increased concentrations were caused by refrozen meltwater that contained eluted ions. However, the data from pit A support a different interpretation. The correlations between species, for example sea-salt species $\left(\mathrm{Na}^{+}, \mathrm{Cl}^{-}, \mathrm{K}^{+}\right.$, $\mathrm{Mg}^{2+}$ ), in the surface winter snow are very similar to those in the layer from autumn 1999 to the bottom of the pit. This indicates that melt from the 2000 and 2001 layers has not refrozen in this layer. The elution rates of species are different (Table 3) and thus the ions are not expected to preserve their original correlations in the refrozen elution water layer. One explanation for the missing ions from the autumn 2001 to autumn 1999 layer may be that they percolated deeper via vertical pipes; however, we would still expect to see some signature during stratigraphic studies or in the ion record of 1999.

Runoff could have occurred because the ice layers were sufficiently thick and uniform to stop the eluting water penetrating through them, hence causing the meltwater to flow downslope or laterally until it was refrozen or could flow across the boundary. In pit A, there was a $4 \mathrm{~cm}$ thick ice layer in the autumn 1999 layer. Higher concentrations are not, however, restricted to this ice layer, but also occur on both sides of it. Thus, most probably it represents an autumnthaw layer that was formed and refrozen in its original location. Moore and others (2005) argue that for the 1997 ice core, deep percolation was a rare occurrence, so the autumn 2001 to autumn 1999 layers may represent an unusual type of melt on the ice cap. We examine that hypothesis in the next subsection.

\section{Pit A compared to the ice-core ion record}

Elution factors (Table 3) were calculated by comparing concentrations in the same layer of snow before (winter surface snow in 2001 snow pits) and after (layer spanning autumns 2001-2000 in pit A) summer melting. The leasteluted species are sodium, chloride, ammonium and potassium. The charge on the ion seems to play an important role during elution, since divalent ions $\left(\mathrm{Ca}^{2+}, \mathrm{Mg}^{2+}\right.$ and $\mathrm{SO}_{4}{ }^{2-}$ ) have the highest elution factors (though $\mathrm{NO}_{3}{ }^{-}$seems to be an exception to this). This contrasts with earlier data that found anions of strong acids were eluted first (e.g. Brimblecombe and others, 1985), but observations in more recent studies (e.g. Cragin and others, 1996) are very similar to ours. Elution of hydrogen ions could not be calculated since $\mathrm{pH}$ was not measured in 2001, but, as mentioned earlier, $\mathrm{pH}$ seems to be a very useful melt indicator with less acidic values in the autumn 2001 to autumn 1999 layer. Also, at Austfonna the dry snow had lower pH values (5.25.3) than the wet snow (5.5-5.6). Therefore some elution of $\mathrm{H}^{+}$occurs during melting.

The elution factor of $\mathrm{NH}_{4}{ }^{+}$is not as reliable as that for other species in the snow pits. The winter surface snow in 2001 snow pits does not include layers with the highest $\mathrm{NH}_{4}{ }^{+}$concentrations since ammonium is expected to peak during warm periods, especially in late summer and autumn, when there are often large forest fires in the Northern Hemisphere and biogenic emissions are greater (Hansson and Holmén, 2001). This can also be seen in the pits where the highest $\mathrm{NH}_{4}{ }^{+}$concentrations are found in spring in fresh snow samples and in autumn layers, for example in the autumn 2001 and 1999 layers in pit A (Fig. 5). However, our estimate of elution factor seems fairly reasonable since $\mathrm{NH}_{4}{ }^{+}$is one of the least eluting species in both the Lomonosovfonna and Austfonna (lizuka and others, 2002) snow pits and the 1997 ice core.

In the 1997 ice core the elution factors (Table 3) were calculated using the concentrations in bubbly and clear ice (Moore and others, 2005). The calculation is based on the assumption that during melting many ions elute from the snowpack and are trapped in clear-ice layers as the water refreezes. Thus the layer where the ions were originally located (bubbly ice) has lower concentrations. The order of elution factors based on ice-core data and snow-pit concentrations are fairly similar but the values are different. For most of the ions the elution factors are two to three times higher in the snow pit than in the ice core. This most probably indicates how serious the melting was during the 2000-01 


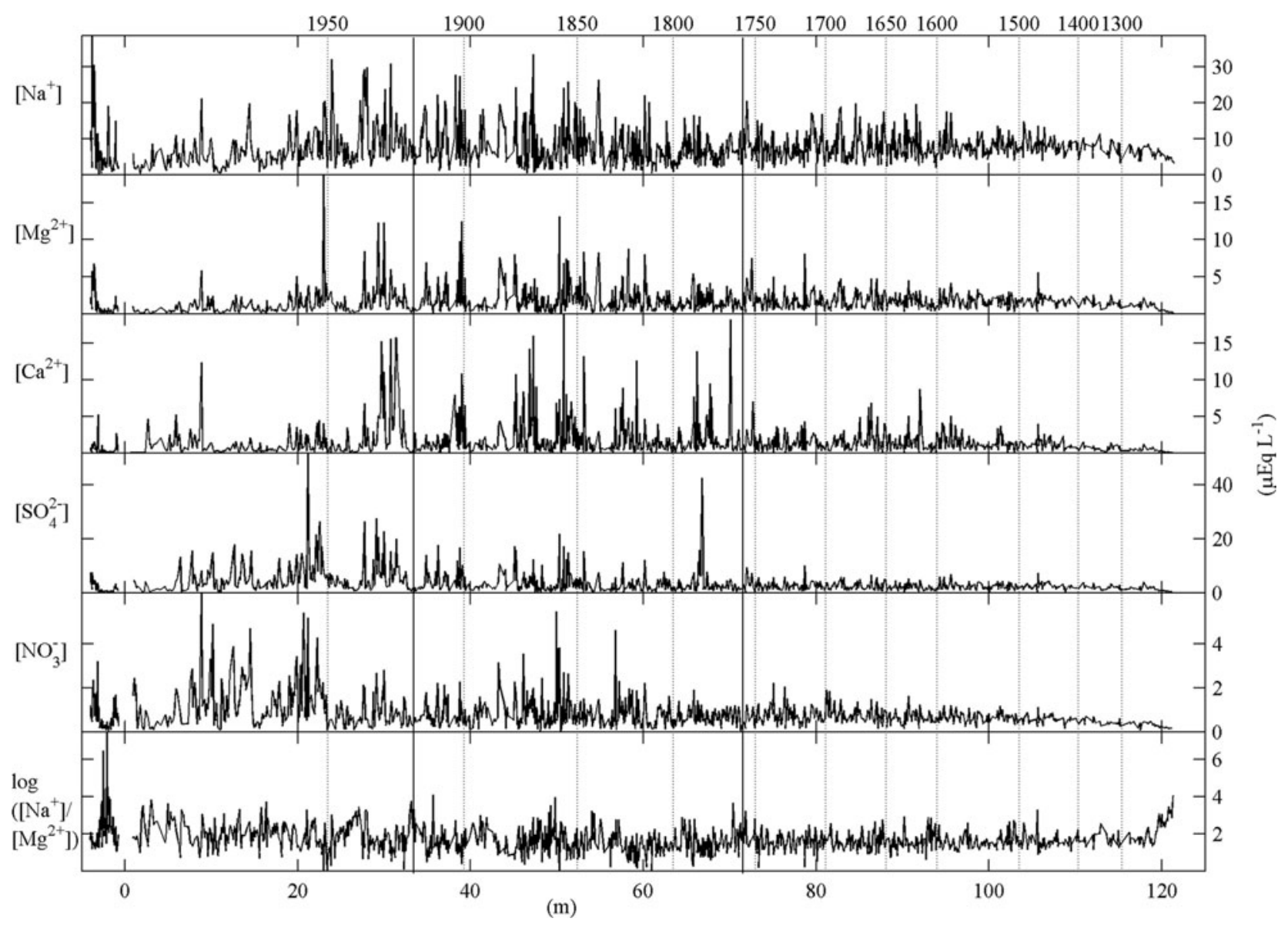

Fig. 7. Snow pit A and the Lomonosovfonna 1997 ice-core ion concentrations plotted in the same figure to enable the visual comparison of the two datasets. Pit A data are plotted from $-4 \mathrm{~m}$ (spring 2002) to $-1 \mathrm{~m}$ (bottom of pit A corresponding to year 1999) and the ice core is represented from approximately $2 \mathrm{~m}$ (1997) until the end of the core $(121 \mathrm{~m})$. Between these two records there is a gap of $\sim 3 \mathrm{~m}(2$ years). Bold vertical lines at 33 and $72 \mathrm{~m}$ show where the species concentrations indicate high melting. This is also seen in the deepest regions of the ice core.

summers and that an unusually large proportion of ions was lost by deep percolation or runoff. Due to its much lower altitude, Austfonna ice cap is more affected by melting than Lomonosovfonna and this can also be seen in the elution factors that were calculated based on the concentrations in dry and wet snow in 1998 (lizuka and others, 2002). The values of the elution factors are similar even though the values at Lomonosovfonna represent layers with serious melting while the summers affecting the formation of 'wet' snow layers at Austfonna were not noted as especially warm.

The most significant difference between the elution factors in the snow pits and those in the 1997 ice core is the location of magnesium in the elution order. According to the ice-core data this ion is the most stable ion in the snowpack during melting. In the snow-pit record, however, magnesium elutes with meltwater similar to other divalent ions and nitrate. As the use of the $\log \left(\left[\mathrm{Na}^{+}\right] /\left[\mathrm{Mg}^{2+}\right]\right)$ melt indicator is based on the assumption of different elution rates for magnesium and sodium, there is an apparent contradiction, that can, however, be resolved. Not all the bubbly layers in the ice core have necessarily experienced melting. If we restrict the calculation to regions where the smoothed (seven-point moving average) stratigraphic melt index (SMI) has a steep slope (absolute gradient larger than $10 \%$ per sample) then we get modified elution factors, $C_{\text {mod, }}$ which are much more consistent with those of pits 1 and 2
(Table 3). Values of the elution factors are higher than before but still not as high as in the snow pits with unusually heavy melting, and the location of $\mathrm{Mg}^{2+}$ in the elution order is similar to the other records.

Data from pit A were plotted together with the 1997 icecore ion record for comparison in Figure 7, where depths from -4 to $-1 \mathrm{~m}$ correspond to snow-pit data from spring 2002 to the bottom of the pit, i.e. autumn 1999. The snowpit data include the layers with substantial melting spanning $\sim 2$ years. In these layers the $\log \left(\left[\mathrm{Na}^{+}\right] /\left[\mathrm{Mg}^{2+}\right]\right)$ melt indicator reaches high values while the concentrations of all species, especially nitrate and divalent ions, are low. Sodium, chloride, potassium and ammonium ions are not as easily eluted and thus their concentrations are slightly higher. The ice-core ion record also contains some parts with both low ion concentrations and high values of $\log \left(\left[\mathrm{Na}^{+}\right] /\left[\mathrm{Mg}^{2+}\right]\right)$. These events are usually very short compared with the autumn 2001 to autumn 1999 layer in the snow pit and are most probably caused by random variations of the ion concentrations. There are, however, some periods that resemble the autumn 2001 to autumn 1999 layer.

We investigate how unusual the pit sample chemistry is, compared with the ice-core record, by computing a washout factor. Since in this case we are looking for periods not only of melting but also when ions were lost by runoff, we use 


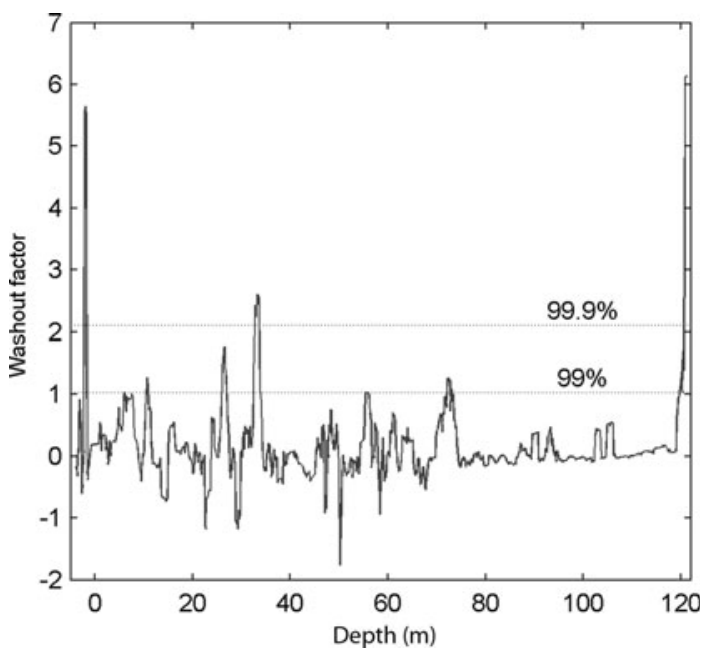

Fig. 8. Washout factor ( $W$ in Equation (1)) as a function of depth in the pit $(0-4 \mathrm{~m})$ and core with an 11-point moving average. Significance levels in Monte Carlo testing are shown.

both melt indices proposed by Grinsted and others (2006), $\log \left(\left[\mathrm{Na}^{+}\right] /\left[\mathrm{Mg}^{2+}\right]\right)$ and $\log \left(\left[\mathrm{Cl}^{-}\right] /\left[\mathrm{K}^{+}\right]\right)$, and the concentrations of divalent ions and nitrate (logged to take account of the log-normal distribution of the ion data) (Moore and others, 2006). At each depth, $d$, the washout factor $W_{d}$ is:

$$
W_{d}=-\bar{X}_{d} \prod_{m=1}^{2} M_{m, d}
$$

where $M_{m}$ are the two standardized (mean, 0; standard deviation, 1) melt indices, and $X$ is the log-normalized concentration of the species, $\mathrm{Ca}^{2+}, \mathrm{Mg}^{2+}, \mathrm{NO}_{3}{ }^{-}$and $\mathrm{SO}_{4}{ }^{2-}$. The significance of $W$ was computed using Monte Carlo methods based on 10000 noise samples with the same autocorrelation and same cross-correlation as the real data. Figure 8 shows a plot of $W$ as a function of depth in pit $\mathrm{A}$ and the ice core, with an 11-point boxcar smoothing window. The snow-pit samples have exceptional washout factors that only compare with data from the bottom few metres of core. There are also a few intervals where $W$ is significant at the $99 \%(11,26$ and $72 \mathrm{~m})$ and one place where it passes the 99.9\% significance level $(33 \mathrm{~m}$ ). Ice-core dating (Pohjola and others, 2002b; Kekonen and others, 2005) shows that $33 \mathrm{~m}$ corresponds to the year 1920. An ice core retrieved from Austfonna (dated back to around 1780) shows also that there has been much more melting after 1920 based on the melt-indicator $\mathrm{Mg}^{2+} / \mathrm{Na}^{+}$values and the firn stratigraphy (lizuka and others, 2002). In 1920 an abrupt warming occurred in the Svalbard temperature record (HanssenBauer and Førland, 1998). Since our method marks this documented warm episode in 1920, we can say that the washout factor is linked to the periods described by warm temperatures and significant amounts of elution. The layer at $72 \mathrm{~m}$ corresponds to approximately $\mathrm{AD} 1750$, and is in the middle of a period of several warm decades in the Lomonosovfonna $\delta^{18} \mathrm{O}$ record (Isaksson and others, 2003). There are also a few similar events in the period from around 1970 to 1997.

The most strikingly similar part of the 800 year record is the section from $119 \mathrm{~m}$ to the bottom of the core. This section is dated by flow modelling (Kekonen and others, 2005), supported by the observation of a highly significant anomalous sulphate signal at $117.6 \mathrm{~m}$ depth that Moore and others (2006) show is likely to be the volcanic eruption in 1259 often seen in ice-core records. The flow model date for this signal is 1244, suggesting that the dating is good to a few per cent back to the 13th century. All ions, except $\mathrm{NH}_{4}{ }^{+}$, $\mathrm{Na}^{+}$and $\mathrm{Cl}^{-}$, fall to values close to zero as the core bottom is approached, even lower than seen in the autumn 2001 to autumn 1999 layer. We have considered the possible impact of diffusion on the ion record and find it an implausible explanation for the decreasing ion profile measured. Diffusion would remove all short-period signals in the ion records before the formation of the long-wavelength drop in ion levels observed. However, the record in Figure 7 shows significant short-period structure in many ions in the bottom $5 \mathrm{~m}$ of the record, ruling out diffusion as a mechanism.

The basal ice does not have any basal debris material entrained within it, nor are there bands of clear and bubbly ice, nor ice containing enriched ion content, hence it is not a basal ice facies of the type sometimes seen in temperate glaciers (e.g. Hubbard and others, 2000). The lowest metres of ice appear very similar to the ice at other depths, except that the crystals are bigger and the layers of clear and bubbly ice are thinner, which is to be expected. Kekonen and others (2005) considered the bottom $10 \mathrm{~m}$ of the core and concluded that flow of ions through the grain-boundary network was too slow to cause any significant loss of ions to the bed, given the observed crystal sizes and temperature profiles. These observations also suggest that ice has not become tainted by elution of ions from melting in contact with the bed of the glacier. So we are left with the same mechanism that seems to have occurred in the autumn 2001 to autumn 1999 layer, involving loss of ions either by percolation or runoff. As the core reached to within $2 \mathrm{~m}$ of the bed and there is no sign of higher concentrations closer to the bed, we suppose that runoff must have occurred.

The MWE is often observed in climate data (e.g. Jones and Mann, 2004; Moberg and others, 2005), and is usually dated as extending from approximately AD 950 to 1200 . There is controversy over how warm the MWE was compared with the present-day climate. One possible cause of rising temperatures could be a reduction in the thickness of the glacier. The Lomonosovfonna ice cap is only $125 \mathrm{~m}$ thick at the drill site, and as lapse rates are $\sim 4^{\circ} \mathrm{C} \mathrm{km}^{-1}$ (Pohjola and others, 2002a), there is potential rise in temperature due to a change in ice thickness of only $0.5^{\circ} \mathrm{C}$, if the ice cap was much thinner in the MWE. Other authors have found lapse rates to vary between $\sim 4$ and $6^{\circ} \mathrm{C} \mathrm{km}^{-1}$ and to be highly dependent on synoptic conditions and local topography (Marshall and others, 2007). Certainly, we can expect that lapse rates may have been different over time, but the present rate is close to the global minimum, suggesting close to saturated water vapour conditions, as, indeed, is to be expected in a strongly maritime environment such as Svalbard. However, if we assume a lapse rate of $6^{\circ} \mathrm{C} \mathrm{km}^{-1}$, the maximum altitudinal warming if the ice cap was very thin is $0.75^{\circ} \mathrm{C}$. This can be compared with the summer 2001 temperatures being $1^{\circ} \mathrm{C}$ warmer than the mean summer (Table 1). It seems unlikely that the ice cap could have formed from snow-free ground in the MWE given the extent of melting we infer. If the glacier was in gross negative mass balance, such that it had almost disappeared in the MWE, it is implied that melting was sufficient at the previous elevation of the ice cap to become much thinner than at present. Therefore the MWE high melt cannot be entirely 
due to altitudinal effects, and we can use the recent pit data to infer summer conditions during the MWE. Based on the melt effects in the Lomonosovfonna ice core we can say that MWE temperatures were likely to have been at least as warm as the summers of 2001 and 2000.

\section{CONCLUSIONS}

Spatially homogeneous ion concentrations in snow pits sampled around the summit of Lomonosovfonna ice cap confirm that the $121 \mathrm{~m}$ long 1997 ice core was drilled from a representative location. The coefficient of variation for different species in winter surface snow is affected by the composition of air masses and accumulation patterns in Lomonosovfonna and Holtedahlfonna. The most evenly mixed species in the air were $\mathrm{H}^{+}, \mathrm{NO}_{3}{ }^{-}$and $\mathrm{SO}_{4}{ }^{-}$, while nssCa ${ }^{2+}$ and $\mathrm{NH}_{4}{ }^{+}$had the highest variability, spanning the spectrum from homogeneously distributed gaseous to spatially variable particulate species. These two locations were clearly very different since in Holtedahlfonna the CV of all ions was higher and, in contrast to Lomonosovfonna, a clear Arctic-haze signature was found.

Dating of the deepest snow pit $(3.27 \mathrm{~m})$ containing a record from the exceptionally warm year, 2001, revealed that during melting the ion concentrations in the residual snow, especially for divalent ions and nitrate, are very low and the most useful melt indicator in Lomonosovfonna, $\log \left(\left[\mathrm{Na}^{+}\right] /\left[\mathrm{Mg}^{2+}\right]\right)$, reaches high values. Our results indicate that air temperature affects the amount of melting more than, for example, the length of the summer or the number of positive degree-days. We suggest that ions were lost either by deep percolation or runoff. The latter, however, seems the more plausible explanation since in the deepest part of the snow pit, where there is no serious melting, there are no signs of deep percolation. Elution factors were found to be similar in the ice core and in the snow pits even though they were based on a comparison of different kinds of layers, i.e. bubbly and clear ice in the ice core and snow before and after melting in the snow pits.

In the ice-core record between the MWE and the $21 \mathrm{st}$ century there were only a few layers similar to the years with an unusual amount of melting in the snow pit (e.g. at $33 \mathrm{~m}$ depth, which corresponds to about 1920) when abrupt warming took place in Svalbard. The most obviously similar layers are in the bottom few metres of the ice core, most likely representing part of the MWE. In addition, the lower part of the oxygen isotope record shows values that are more positive than during the Little Ice Age, and are similar to those in the 20th century (personal communication from T. Martma, 2007). We conclude that, during that period, conditions for melting were similar to the summer of 2001. The small number of heavy melt layers suggesting unusual melt, together with a lack of evidence of runoff through most of the ice, confirm that the 1997 ice core drilled from Lomonosovfonna can be used for reliable palaeoclimatic reconstructions.

\section{ACKNOWLEDGEMENTS}

We thank the Finnish Forest Research Institute, Rovaniemi Research Unit for cold-room and clean-room facilities. Financial support came from the Finnish Academy. The Norwegian Polar Institute supported the fieldwork in Svalbard. We thank all the people who helped with the snow-pit sampling and fieldwork arrangements. We also thank P. Głowacki (Institute of Geophysics, Polish Academy of Sciences) who provided the temperature and precipitation data from the Polish Polar Station in Hornsund.

\section{REFERENCES}

Bales, R.C., R.E. Davis and M.W. Williams. 1993. Tracer release in melting snow: diurnal and seasonal patterns. Hydrol. Process., 7(4), 389-401.

Battye, W., V.P. Aneja and P.A. Roelle. 2003. Evaluation and improvement of ammonia emissions inventories. Atmos. Environ., 37(27), 3873-3883.

Brimblecombe, P., M. Tranter, P.W. Abrahams, I. Blackwood, T.D. Davies and C.E. Vincent. 1985. Relocation and preferential elution of acidic solute through the snowpack of a small, remote, high-altitude Scottish catchment. Ann. Glaciol., 7, 141-147.

Cragin, J.H., A.D. Hewitt and S.C. Colbeck. 1996. Grain-scale mechanisms influencing the elution of ions from snow. Atmos. Environ., 30(1), 119-127.

Głowacki, P. and M. Pulina. 2000. The physico-chemical properties of the snow cover of Spitsbergen (Svalbard) based on observations during the winter season 1990/1991. Pol. Polar Res., 21(2), 65-88.

Głowacki, P., W.E. Krawczyk and T. Niedzwiedz. 2002. Precipitation in Hornsund (SW Spitsbergen) in summers of 2000 and 2001 - its chemistry and influence of atmospheric circulation. In International Conference Proceedings Collection - the complex investigations of the Spitsbergen nature. Murmansk Russian Academy of Sciences. Kola Science Centre, 112-116.

Goto-Azuma, K., R.M. Koerner and D.A. Fisher. 2002. An ice-core record over the last two centuries from Penny Ice Cap, Baffin Island, Canada. Ann. Glaciol., 35, 29-35.

Grinsted, A., J.C. Moore, V. Pohjola, T. Martma and E. Isaksson. 2006. Svalbard summer melting, continentality and sea ice extent from the Lomonosovfonna ice core. J. Geophys. Res., 111(D7), D07110. (10.1029/2005JD006494.)

Hanssen-Bauer, I. and E.J. Førland. 1998. Long-term trends in precipitation and temperature in the Norwegian Arctic: can they be explained by changes in atmospheric circulation patterns? Climate Res., 10(2), 143-153.

Hansson, M. and K. Holmén. 2007. High latitude biospheric activity during the last glacial cycle revealed by ammonium variations in Greenland ice cores. Geophys. Res. Lett., 28(22), 4239-4242.

Hara, K., K. Osada, M. Hayashi, K. Matsunaga and Y. Iwasaka. 1997. Variation of concentrations of sulfate, methanesulfonate and sulfur dioxide at Ny Allesund in 1995/96 winter. Proc. NIPR Symp. Polar Meteorol. Glaciol. 11, 127-137.

Hewitt, C.N. and W.T. Sturges, eds. 1993. Global atmospheric chemical change. London, Elsevier Applied Science.

Houghton, J.T. and 7 others. 2001. Climate change 2001: the scientific basis. Contribution of Working Group I to the Third Assessment Report of the Intergovernmental Panel on Climate Change. Cambridge, etc., Cambridge University Press.

Hubbard, B., J.L. Tison, L. Janssens and B. Spiro. 2000. Ice-core evidence of the thickness and character of clear-facies basal ice: Glacier de Tsanfleuron, Switzerland. J. Glaciol., 46(152), 140-150.

Hunt, B.G. 1998. Natural climatic variability as an explanation for historical climatic fluctuations. Climatic Change, 38(2), 133-157.

lizuka, Y., M. Igarashi, K. Kamiyama, H. Motoyama and O. Watanabe. 2002. Ratios of $\mathrm{Mg}^{2+} / \mathrm{Na}^{+}$in snowpack and an ice core at Austfonna ice cap, Svalbard, as an indicator of seasonal melting. J. Glaciol., 48(162), 452-460.

Isaksson, E. and 14 others. 2001. A new ice-core record from Lomonosovfonna, Svalbard: viewing the 1920-97 data in relation to present climate and environmental conditions. J. Glaciol., 47(157), 335-345. 
Isaksson, E. and 11 others. 2003. Ice cores from Svalbard: useful archives of past climate and pollution history. Phys. Chem. Earth, 28, 1217-1228.

Jauhiainen, T., J. Moore, P. Perämäki, J. Derome and K. Derome. 1999. Simple procedure for ion chromatographic determination of anions and cations at trace levels in ice core samples. Anal. Chim. Acta, 389(1), 21-29.

Jickells, T.D. and 7 others. 2003. Isotopic evidence for a marine ammonia source. Geophys. Res. Lett., 30(7), 1374. (10.1029/ 2002GL016728.)

Jones, P.D. and M.E. Mann. 2004. Climate over past millennia. Rev. Geophys., 42(2), RG2002. (10.1029/2003RG000143.)

Kekonen, T., J.C. Moore, R. Mulvaney, E. Isaksson, V. Pohjola and R.S.W. van de Wal. 2002. An 800 year record of nitrate from the Lomonosovfonna ice core, Svalbard. Ann. Glaciol., 35, 261-265.

Kekonen, T., P. Perämäki and J.C. Moore. 2004. Comparison of analytical results for chloride, sulfate and nitrate obtained from adjacent ice core samples by two ion chromatographic methods. J. Environ. Monit., 6(2), 147-152.

Kekonen, T. and 6 others. 2005. The 800 year long ion record from the Lomonosovfonna (Svalbard) ice core. J. Geophys. Res., 110(D7), D07304. (10.1029/2004JD005223.)

Marshall, S.J., M.J. Sharp, D.O. Burgess and F.S. Anslow. 2007. Near-surface-temperature lapse rates on the Prince of Wales Icefield, Ellesmere Island, Canada: implications for regional downscaling of temperature. Int. J. Climatol., 27(3), 385-398.

Moberg, A., D.M. Sonechkin, K. Holmgren, N.M. Datsenko and W. Karlén. 2005. Highly variable Northern Hemisphere temperatures reconstructed from low- and high-resolution proxy data. Nature, 433(7026), 613-617.

Moore, J.C., A. Grinsted, T. Kekonen and V. Pohjola. 2005. Separation of melting and environmental signals in an ice core with seasonal melt. Geophys. Res. Lett., 32(10), L10501. (10.1029/2005GL023039.)

Moore, J.C., T. Kekonen, A. Grinsted and E. Isaksson. 2006. Sulfate source inventories from a Svalbard ice-core record spanning the Industrial Revolution. J. Geophys. Res., 111(D15), D15307. (10.1029/2005JD006453.)
Niedźwiedź, T. 1997. Czástoéá wystápowania typ’w cyrkulacji nad Spitsbergen (1951-1995). [Frequency of circulation patterns above Spitsbergen (1951-1995)]. Probl. Klimatol. Polarnerj, 7, 9-16. [In Polish with English summary.]

Pohjola, V. and 7 others. 2002a. Effect of periodic melting on geochemical and isotopic signals in an ice core on Lomonosovfonna, Svalbard. J. Geophys. Res., 107(D4), 4036. (10.1029/ 2000JD000149.)

Pohjola, V.A. and 6 others. 2002b. Reconstruction of three centuries of annual accumulation rates based on the record of stable isotopes of water from Lomonosovfonna, Svalbard. Ann. Glaciol., 35, 57-62.

Semb, A., R. Brækkan and E. Joranger. 1984. Major ions in Spitsbergen snow samples. Geophys. Res. Lett., 11(5), 445-448.

Sharp, M., M. Skidmore and P. Nienow. 2002. Seasonal and spatial variations in the chemistry of a High Arctic supraglacial snow cover. J. Glaciol., 48(160), 149-158.

Simôes, J.C. and V.S. Zagorodnov. 2001. The record of anthropogenic pollution in snow and ice in Svalbard, Norway. Atmos. Environ., 35(2), 403-413.

Staebler, R. and 6 others. 1999. Physical and chemical characteristics of aerosols at Spitzbergen in the spring of 1996. J. Geophys. Res., 104(D5), 5515-5529.

Teinilä, K., R. Hillamo, V.M. Kerminen and H.J. Beine. 2004. Chemistry and modal parameters of major ionic aerosol components during the NICE campaigns at two latitudes. Atmos. Environ., 38(10), 1481-1490.

Tsiouris, S., C.E. Vincent, T.D. Davies and P. Brimblecombe. 1985. The elution of ions through field and laboratory snowpacks. Ann. Glaciol., 7, 196-201.

Twickler, M. and S. Whitlow. 1997. Appendix B: Guide for the collection and analysis of ITASE snow and firn samples. In Mayewski, P.A. and I.D. Goodwin, eds. International TransAntarctic Scientific Expedition (ITASE). Bern, Past Global Changes. (PAGES Report 97-1)

Virkkunen, K. 2004. Snowpit studies in 2001-2002 in Lomonosovfonna, Svalbard. (MSc thesis, University of Oulu.)

Zhang, Y., S. Liu and Y. Ding. 2007. Glacier meltwater and runoff modelling, Keqicar Glacier, southwestern Tianshan, China. J. Glaciol., 53(180), 91-98. 